\title{
HTS Theological Studies \\ and Verbum et Ecclesia - \\ the journals of the Faculty of \\ Theology at the \\ University of Pretoria: \\ Historical overview and strategic \\ planning
}

\author{
Dirk Human \& Andries van Aarde ${ }^{1}$ \\ Faculty of Theology \\ University of Pretoria
}

\begin{abstract}
This article celebrates the centenary of the University of Pretoria (UP) in 2008. The editors of Verbum et Ecclesia and HTS Theological Studies, the two theological journals associated with the Faculty of Theology at UP, reflect on the journals' historical roots, editorial focuses, distinctive features, subscription and language statistics and on their' contribution to support the academic study of theology and related disciplines. The Faculty of Theology was founded in 1917 and celebrated its ninetieth birthday in 2007. The origin of its journals dates back to 1943. This article discusses the challenges that academic journals face in South Africa and undertakes strategic planning for the future. A concluding addendum, consisting of statistical diagrams with regard to the journals' profile during the last five years, illustrates the argument.
\end{abstract}

\section{INTRODUCTION}

The South African Department of Education (DoE) subsidises higher educational institutions in South Africa if research output is published in one of

\footnotetext{
${ }^{1}$ Dirk J Human is the editor of Verbum et Ecclesia and Andries G van Aarde the editor of HTS Theological Studies. Professor Human is Professor in Old Testament Studies at the Faculty of Theology and Professor Van Aarde is honorary professor at the Faculty of Theology, University of Pretoria. This historical report on the journals of the Faculty of Theology at the University of Pretoria is written against the background of the centenary celebration of the University of Pretoria in 2008.
} 


\section{Verbum et Ecclesia and HTS Theological Studies}

the journals that appear on the list of approved academic journals and the author is associated with the accredited tertiary institution. In order to procure accreditation an approved scholarly journal has to comply with international standards. The following ten criteria could be regarded as internationally acknowledged criteria: (1) original and innovative research, (2) peer review, (3) peer recognition, (4) scholarly impact, (5) language accessibility through abstracts, (6) international indexing, (7) impact and accessibility through broad library subscription, individual/institutional circulation, institutional responsibilities, and open electronic access , (7) international editorial quality control and management, (8) orthographical and printing quality according to a recognised reference system (9) the inclusion of book reviews, and (10) adherence to schedule.

At the University of Pretoria two theological journals are associated with the Faculty of Theology. Both journals appear on the list of South African accredited academic journals. The two journals represent different theological interest groups.

HTS Theological / Teologiese Studies (HTS) is affiliated with the Reformed Theological College (HTK). In 2000 a contractual agreement was reached between the University of Pretoria and the Netherdutch Reformed Church of Africa (NHKA) ${ }^{2}$ in terms of which the Reformed Theological College $(\mathrm{HTK})^{3}$ was affiliated to the Faculty of Theology. Clause 7.2 of this agreement describes the position of HTS Theological Studies:

Hervormde Teologiese Studies [HTS Theological Studies] is a scholarly journal associated with the Faculty of Theology and accredited by the Department of Education in terms of specific scholarly criteria. The administration of HTS Theological Studies is managed by the Faculty of Theology's Reformed Theological College (HTK) and it falls under the auspices of the Netherdutch Reformed Church of Africa (NHKA). The Reformed Theological College (HTK) is responsible to ensure that the criteria for accreditation are met and upheld. Accreditation is a condition for tertiary institutions in South Africa to receive a financial subsidy from the Department of Education for published research outputs of South African academics and their registered research associates. The publication of articles of academics associated to the University of Pretoria in HTS Theological Studies will be for the benefit of the Faculty of Theology and the

\footnotetext{
${ }^{2}$ The official name in Afrikaans is: Nederduitsch Hervormde Kerk van Afrika (NHKA).

${ }^{3}$ The official name in Afrikaans is: Hervormde Teologiese Kollege (HTK).
} 
University of Pretoria. The Reformed Theological College (HTK) is responsible for the financial management, infrastructure, printing, subscription and distribution of HTS Theological Studies. The research projects of the permanent academic staff and their research associates attached to the Reformed Theological College (HTK) will benefit from the budget of the Faculty of Theology which receives financial subsidy as a result of their research outputs in accredited scholarly journals (translation by $A \mathrm{G} \vee \mathrm{A}$ ).

According to the contract agreed upon by the University of Pretoria and the Netherdutch Reformed Church of Africa (NHKA) as co-partner in the multiecclesiastic Faculty of Theology in support of the training of students for ministry, the financial credits generated by the publications of research outputs in HTS Theological Studies will be taken into account when the number of academic personnel is officially contracted by the University of Pretoria.

Verbum et Ecclesia ( $V E$ ) functions under the auspices of two centres at the University of Pretoria's Faculty of Theology, namely the Institute for Missiological and Ecumenical Research (IMER) and the Centre for Theology and Community. Verbum et Ecclesia was established in 1980 and the journal's historical roots are to be found in the Faculty of Theology (Section B). At the time of its establishment the journal's title was Skrif en Kerk. During the early days of the journal's existence, Prof Dr W S (Riempies) Prinsloo was its first editor and played a major role in building its academic importance. In view of the University of Pretoria's policy of internationalisation and to make the journal more accessible, its name was changed in 2001 to Verbum et Ecclesia. As a result, the journal grew in international stature and publishes two (sometimes three) editions annually. The lecturers' council consisting of the professors linked to the Dutch Reformed Church, ${ }^{4}$ together with its international advisory board, constitutes the redaction and selection committee.

HTS Theological Studies was founded in $1943^{5}$ as a result of an international endeavour involving Dutch and South African scholars. It is the

\footnotetext{
${ }^{4}$ The official name in Afrikaans is: Nederduitse Gereformeerde Kerk (NG Kerk).

${ }^{5}$ HTS Theological Studies is also known by its Afrikaans name Hervormde Teologiese Studies (HTS). For a historical overview of HTS' first 50 years, see A D Pont (1994), Die Hervormde Teologiese Studies na vyftig jaar. HTS 50(1\&2), 8-13.
} 
oldest South African theological journal ${ }^{6}$ and publishes four editions annually. Prof Dr J de Zwaan (Leiden), Prof Dr H W Obbink (Utrecht) and Prof Dr B Gemser (Groningen) from the Netherlands played an influential role in the first editorial board, together with the Dutch-born internationally recognised Old Testament scholar Prof Dr A van Selms (see Pont 1994:10). Academics from the University of Pretoria who served onon the editorial board together with Professor Van Selms and the above-mentioned Dutch scholars during the first four years of its existence until 1947/1948 were Professors J H J A Greyvenstein (New Testament Studies and Practical Theology), S P Engelbrecht (Church History) and A S Geyser (New Testament Studies).

At the occasion of HTS's fiftieth anniversary church historian, Emeritus Professor Adriaan Pont (1994:9) describes the policy and contribution of HTS during its initial years as follows in his tribute (translation by $A G \vee A$ ): "From its beginning the Studies was managed and controlled by theological faculty [the Faculty of Theology] and initially it was a mirror which reflected the research and the thoughts of the [members] of the theological faculty. Soon it became clear that the theological faculty wanted to make a positive contribution to the theological debate in and around the church" (Pont 1994:9).

\section{POSITION IN THE ACADEMIC WORLD}

The redactional policies of both journals are closely related to the vision of the University of Pretoria, namely, to be nationally relevant and internationally competitive. The editors of both journals follow a strategy to ensure balanced publication of local, national and international research. Strict international and scholarly criteria are applied in the publication of all articles (see again the

\footnotetext{
${ }^{6}$ Seen from another perspective, the "Theological and Philological Review" of the Greek Orthodox Patriarchate of Alexandria (Egypt), namely Ekklesiastikos Pharos, which celebrated its $89^{\text {th }}$ year of existence in 2007 , could be considered to be the oldest existing scholarly ecclesial journal in South Africa. However, the New Series of this journal, under the auspices of His Beatitude Patriarch Theordorus B, is only for the past 18 years published in South Africa by the Institute for Afro-Hellenic Studies, in collaboration with the Department of Greek and Latin Studies at the University of Johannesburg. Ekklesiastikos Pharos is the "mouthpiece" of the South African Association for Patristic and Byzantine Studies. Although it is already in its 89th [now actually $90^{\text {th }}$ ] year of existence, Ekklesiastikos Pharos exists in South Africa only as "New Series" (see Hendrickx 2007).
} 
article's first paragraph). Both journals have editorial and advisory boards, on which highly regarded international scholars and national academics serve. ${ }^{7}$

Since its foundation in 1980, Verbum et Ecclesia 's (then Skrif en Kerk) infrastructure has been embedded partly in the Faculty of Theology at the University of Pretoria and partly in the Centre for Theology and Community of the Dutch Reformed Church (one of the University of Pretoria's partners as far as theological education is concerned). Verbum et Ecclesia is the scholarly journal of the Society for Ecumenical Research, the Centre for Theology and Community and the Desmond Tutu Chair for Future Studies and Leadership. Its International Advisory Board consists, amongst others, of members with Roman Catholic, Anglican, Lutheran, Methodist, Reformed and Presbyterian denominational affiliations. These members are internationally renowned university scholars and/or clergy. Over a period of one year, two issues (Numbers) are published per volume. A third edition is published periodically as a commemoration edition, or as a special edition dealing with a specific subject or topic. According to its constitution the journal's aim is to make a

\footnotetext{
${ }^{7}$ The editorial board of Verbum et Ecclesia (see Human \& Groenewald 2007) consists of Prof Dr D J Human (editor) and Dr A Groenewald (assistant editor), Prof Dr C J A Vos (University of Pretoria - chairperson), Ms B Bam (Formerly World Council of Churches, Geneva), Prof Dr C T Begg (Washington, DC), Prof Dr P G Braulik (Vienna), Bishop M Dandala (Methodist Church, SA), Prof Dr E de Villiers (University of Pretoria), Dr. P R du Toit (Dutch Reformed Church), Prof Dr G Heitink (Amsterdam), Prof Dr J Jeremias (München), Prof Dr H-J Klauck (Chicago), Prof Dr J H le Roux (University of Pretoria), Dr E Mahlangu (SAST, Rustenburg, SA), Prof Dr M Masango (University of Pretoria), Prof Dr B J Malina (Omaha, USA), Prof Dr P G J Meiring (University of Pretoria), Prof Dr E Mouton (University of Stellenbosch), Prof Dr J C Müller (University of Pretoria), Prof Dr E Otto (München, Germany), Dr S Moyise (London), Prof Dr G J Pillay(Liverpool, Hope University College, UK), Dr J Seoka (Church of the Province of SA), Prof Dr J G van der Watt (University of Pretoria), Prof Dr H C van Zyl (University of the Free State, South Africa), Dr E Usue (Mkar-Gboko, Nigeria), and Prof Dr C $\mathrm{J}$ Wethmar (University of Pretoria). At the beginning of 2008 the editorial board of HTS Theological Studies comprises: Prof Dr Andries G van Aarde (editor), Prof Dr J Buitendag (University of Pretoria - chairperson), Prof Dr Riet Bons-Storm (Emeritus Professor, University of Groningen, the Netherlands), the Rev Dr Richard Burridge FKC (King's College, University of London), Prof Dr T F J Dreyer (Chair: Reformed Theological College at the University of Pretoria), Prof Dr Yolanda Dreyer (Practical Theology, University of Pretoria), Prof Dr Elaine Graham (University of Manchester, UK), Prof Dr David Grafton (Lutheran Theological Seminary in Philadelphia, PA, USA), Prof Dr A I C Heron (University of ErlangenNürnberg, Germany), Prof Dr Knud Jeppesen (Emeritus Professor, Aarhuys University, Denmark and Emeritus Vice-Rector, Tantur Institute of Ecumenical and Theological studies, Jerusalem, Israel), Prof Dr John S Kloppenborg (Trinity College, Toronto, Canada), Dr J P Labuschagne (Church History and Church Polity, University of Pretoria), Prof Dr J A Loader (Dean, University of Vienna, Austria), Dr J-C Loba Mkole (United Bible Societies, Nairobi, Kenya), Prof Dr J Muis (Protestant Theological University, Utrecht, the Netherlands), Prof Dr J H Neyrey (University of Notre Dame, USA), Prof Dr Carolyn Osiek (Brite Divinity School, Texas Christian University, USA), Dr L S Rukundwa (Eben-Ezer Ministry International, Bujumbura, Burundi), Prof Dr W Schmithals (Emeritus Professor, Von Humboldt University, Berlin), Dr David Sim (Australian Catholic University, Melbourne, Australia), Prof Dr A van de Beek (Free University of Amsterdam, the Netherlands), Prof Dr P J van der Merwe (Missiology and Science of Religion, University of Pretoria), Prof Dr Ernest van Eck (New Testament Studies, University of Pretoria), Prof Dr P Venter (Old Testament Studies, University of Pretoria), Prof Dr Elaine Wainwright (University of Auckland, New Zealand).
} 
theological contribution in South Africa by supporting theologians, philosophers, scholars and ministers of religion in religious, social and ecumenical related subjects by means of original research. Since the founding of the journal, scholars from abroad have been attracted to co-contribute to the journal. Research outputs submitted for subsidy by the Department of Education, are strictly peer reviewed according to internationally recognised criteria. The editorial board does not necessarily endorse the views of authors, but academic discourse is promoted through the journal.

Although the two journals are attached to specific academic interest groups, both journals publish an increasing number of articles written by foreign scholars. ${ }^{8}$ The subscribers to Verbum et Ecclesia are mainly graduated pastors and theologians who had studied for ministry in the Dutch Reformed Church (NG Kerk), and in the case of HTS Theological Studies those who had studied for ministry in the Netherdutch Reformed Church of Africa (NHKA).

The historical roots of HTS Theological Studies date back to 1942 when the Cape Town based international Dutch company HAUM/Du Buissy Publishing House became the first sponsor of the initiative taken by theologians of the University of Pretoria in co-operation with scholars in the Netherlands. At the time, the theologians were responsible for theological quality management, while HAUM/du Buissy Publishing House provided the administrative infrastructure. HTS' rights were later sold to the Netherdutch Reformed Church of Africa (NHKA). The then N.H.W. Press (owned by the NHKA) printed HTS Theological Studies and the administration of the journal was handled by staff attached to the Church Synod office in Pretoria. Over the years, close collaboration as far as the infrastructure and scholarly quality of HTS were concerned developed between the Netherdutch Reformed Church of Africa (NHKA) and the Faculty of Theology (then Section A) at the University of Pretoria, founded in 1917 In view of the amalgamation of the two sections (the Dutch Reformed Church [NG Kerk, Section A] and the Netherdutch Reformed Church of Africa [NHKA], Section B) of the Faculty of Theology in 2000 (in collaboration with the Uniting Presbyterian Church of South Africa), the General Synod of the Netherdutch Reformed Church of Africa (NHKA) decided that the newly established Reformed Theological College should be responsible for the infrastructure of HTS Theological Studies. Previously, HTS Theological Studies was supported by and accredited with the then National Bureau for Scientific Publications.

The language of both journals, which used to be Afrikaans, has drastically changed over the past three years to being predominantly English, with other foreign languages also included (see statistical index below). The change in language increased the impact factor of both journals, as well as

\footnotetext{
${ }^{8}$ See statistics in Addendum of article.
} 
the international accessibility of the research results. Both journals are widely indexed on lists in the theological academic world. Fifteen articles by scholars from abroad appeared in Volume 62 (2006) of HTS Theological Studies. In Volume 63 (2007) the number articles written by international scholars were fourteen; and in the case of Volume 64 (2008) - the year of the University of Pretoria's centenary celebration - twenty three articles by scholars from abroad have been submitted and after peer-review, accepted for publication in HTS Theological Studies. In Verbum et Ecclesia, which appears biannually, sixteen international contributions have been published over the last two years (2006-7). During 2005, more than 20 articles by foreign international researchers were published in the two journals, while 20 articles appeared in Afrikaans, 48 in English and two in other European languages. The language tendency also reflects the tendency in the language of theological research undertaken at the Faculty of Theology as its "operational basis". On average, only $40 \%$ of UP's own staff members (including researchers from the Faculty of Humanities and the Faculty of Theology) publish annually in the HTS Theological Studies and in Verbum et Ecclesia. All the othercontributions are received from non-UP researchers attached to other institutions in South Africa and abroad.

A list of South-African scholarly journals ${ }^{9}$ is recognised by the Department of Education (DoE) for subsidy purposes, and in addition, other approved South African and international journals are accredited on the condition that they are accepted by and included in two international indexes, namely the International Bibliography of the Social Sciences (IBSS - based in

\footnotetext{
${ }^{9}$ The editors of South-African based theological and related journals established themselves officially in 2007 as the Editors' Forum for Theology and Related Journals (EFTJ). EFTJ aims to represent the interests of its member journals at the ASSAf's Forum of Editors of South African Research Journals. The list of South-African based journals includesthe following: Dutch Reformed Theological Journall NGTT (editor: Prof Pieter Coertzen, University of Stellenbosch), HTS Teologiese/Theological Studies (editor: Prof Andries G van Aarde, University of Pretoria), In die Skriflig (editor: Prof J M [Koos] Vorster, University of NorthWest), Neotestamentica (editor: Prof Jonathan Draper, University of Kwazulu-Nata), Missionalia (editor: Prof J N J [Klippies] Kritzinger, University of South Africa), Old Testament Essays (editor: Prof P J [Phil] Botha, University of Pretoria), Practical Theology in South Africa (editor: prof Malan Nel, University of Pretoria), Studia Historiae Ecclesiasticae (editor: Prof Christina Landman, University of South Africa), Verbum et Ecclesia (editor: Prof Dirk J Human, University of Pretoria), Theologia Viatorum (editor: Prof Helen Efthimiadis-Keith, University of Limpopo), South African Baptist Journal of Theology (editors: Dr Gordon Miller and Dr Peter Christofides, Cape Town Baptist Seminary), Journal of Theology for Southern Africa (editor: Prof Steve de Gruchy, University of KwaZulu-Natal), Acta Patristica et Byzantina (editor: Prof Hennie F Stander, University of Pretoria), Scriptura (editor: Prof Hendrik J Bosman, University of Stellenbosch), Ekklesiastikos Pharos (editor: Proff Theckla and Ben Hendrickxs, University of Johannesburg), Journal of Constructive Theology (editor: Dr Sarojini Nadar, University of KwaZulu-Natal), Journal of Theology and Religion in Africa (editor: Prof S Moripe, University of Limpopo), Acta Theologica (editor: prof Francois Tolmie, University of the Free State).
} 
London) and the Institute for Scientific Information (ISI Database - based in Philadelphia, USA). Since the ISI and IBSS lists are not accurate measuring instruments for the impact of the Humanities (such as Theology), alternative exposure for these journals has to be sought and recognized. ${ }^{10}$

HTS Theological Studies is indexed on the following national and international journal lists: Religion Index One: Periodicals, Index to Book Reviews in Religion, Religion Indexes: On CD-ROM and ATLA Religion Database on CD-ROM. This periodical is indexed in the ATLA Religion Database, published by the American Theological Library Association, Chicago; Elenchus of Biblical Bibliography of the Editrice Pontificio Institutio Biblico, Rome, Italy; Index to Book Reviews in Religion; International Bibliography of Periodical Literature (IBZ) and International Bibliography of Book Reviews of Scholarly Literature, Osnabrück, Germany; International Glossary of Abbreviations for Theology and Related Subjects (IAGT) Walter de Gruyter, Berlin; New Testament Abstracts, Weston School of Theology, Cambridge, MA; Old Testament Abstracts, Catholic University of America, Washington, DC; Religious and Theological Abstracts, 121 South College Street, Myerstown, PA; Religion Index One: Periodicals; The Voice of the Book, Belgium; Zeitschriften Inhaltsdienstes; Index to South African Periodicals (ISAP); SABINET Online (South African Information Network); South African Theological Bibliography (electronic resource).

Similarly, Verbum et Ecclesia is indexed on the following lists: ATLA Religion Database (until 2005 on CD Rom), BILDI (Indexing abstracts in the German academic world, Innsbruck, Austria; Elenchus of Biblical Bibliography of the Editrice Pontificio Institutio Biblico, Rome, Italy; International Bibliography of Periodical Literature (IBZ); International Bibliography of Book Reviews of Scholarly Literature, Osnabrück, Germany (IZBG), Old Testament Abstracts, New Testament Abstracts, Index to South African Periodicals (ISAP); SABINET Online and South African Theological Bibliography.

As a result of this indexing,both Verbum et Ecclesia and HTS Theological Studies are cited nationally and internationally at various theological conferences, in religious books, in Biblical commentaries, in various scholarly articles and on the internet.

\section{PURPOSE AND SCOPE}

Since the establishment of HTS Theological Studies and Verbum et Ecclesia, their readership e includes academics, theologians, scholars in the fields of humanities, social studies, as well as professional pastors, ministers of

\footnotetext{
${ }^{10}$ See Rademeyer, A 2006. Universiteit-kwaliteit is relatief, sê kenners: Vermeldings "nie die enigste maatstaf vir instellings". Beeld, Donderdag 16 November 2006.
} 
religion, and readers who take an academic interest in religious matters. The journals cover theology in its broadest sense and therefore publish articles that are linked to a variety of other study fields. Thus, they have a multidisciplinary, multi-church, inter-faith and multi-religious focus and scope. HTS Theological Studies and Verbum et Ecclesia are committed to the development of young scholars.

Like philosophy, theology fulfils multi-disciplinary role in the academic environment]in the academic environment. Theology serves as a cohesive study field for a variety of sciences. Since theology is not only a study field aimed at the education of pastors or ministers of religion, it also links with a variety of other study fields. HTS Theological Studies and Verbum et Ecclesia therefore have a multi-disciplinary, multi-church, inter-faith and multi-religious focus and cover amongst others, aspects of religious studies, philosophy, ancient Semitic and classical languages, sociology and ethics.

Both journals make a meaningful theological contribution in South Africa, in Africa and in the international world by supporting theologians, philosophers, scholars and ministers of religion in their study of religious, social and ecumenical related subjects by means of original and sound research. HTS Theological Studies and Verbum et Ecclesia count among the first 100 academic journals as far as frequency of articles published in scientific journals is concerned. With its 4 editions per annum, HTS Theological Studies is ranked in the fourteenth place, while Verbum et Ecclesia finds itself in the $69^{\text {th }}$ position with its twoeditions per annum. ${ }^{11}$

\section{STRATEGIC PLANNING FOR THE FUTURE}

The editors of both Verbum et Ecclesia (VE) and HTS Theological Studies (HTS) do not consider these journals to be "categorised" as so-called "in house" journals because of VES and HTS' close association with the Faculty of Theology at the University of Pretoria. "In house journals" can be defined as "local journals" in which only (or mainly) articles by researchers attached to a

\footnotetext{
${ }^{11}$ Based on CREST's research, Prof Johann Mouton published certain findings in an article which appeared in Tydskrif vir Geesteswetenskappe 45(3) 2005. Based on data covering a twelve year period as recorded in SA Knowledge base (SAK), this research deals with tendencies pertaining toSouth African accredited journals. In 1990 in both the Natural Sciences and Social Studies (published in Afrikaans, English and other European languages) a total of 6617 articles were published in South Africa and in 2002, a total of 5737 (see J Mouton in Tydskrif vir Geesteswetenskappe 45/3, 2005). More than $45 \%$ of these articles were published in 100 journals. With regard to the highest frequency, HTS Theological Studies is listed in the $14^{\text {th }}$ position. In this instance, "frequency" refers to the researchers' preference for a specific journal in which to publish their outputs. Those journals with a higher frequency are mainly journals of Medicine, Law and Education. The NGTT (a scholarly theological publication of the NG Church assocaited to the University of Stellenbosch), is listed in the $22^{\text {nd }}$ position.
} 
particular institution responsible for the journal are published and do not comply with the following criteria for accreditation: ${ }^{12}$

- original and innovative research;

- peer review;

- peer recognition;

- scholarly impact;

- language accessibility through abstracts;

- international indexing;

- impact and accessibility through broad library subscription and individual/institutional circulation;

- international editorial quality control and management;

- acknowledged reference system;

- orthographical and printing quality;

- the inclusion of book reviews;

- adherence to schedule.

The accreditation of theological journals on the ISI and IBSS international lists is highly problematic, since these lists' focus is more on the nature and interests of the empirical Social Studies and the Natural Sciences. ISI and IBSS are First World dominated lists. The promotion of Third World theological and religious perspectives, therefore, depends on African and South African initiatives.

According to the ASSAf report of 2006 on a national strategic framework for South African research journals, the following categories of journals are accepted as subsidised, accredited scholarly journals by the Department of Education. They include journals indexed in international indexes (e.g. ISI and IBSS), "local" scholarly journals initiated by learned societies that represent specialisation fields and "local" scholarly journals initiated by academic interest groups such as academic schools/ universities/ faculties and institutions that promote academic research. Both HTS Theological Studies and Verbum et Ecclesia are excellently positioned as far as the third category is concerned.

Since 2002, the editorial boards of both journals have unsuccessfully attempted to affiliate with ISI and IBSS. These applications are per definition unsuccessful, because the indexes are not concerned with theology as such. In the case of ISI, according to responsive correspondence to the editor of

\footnotetext{
${ }^{12}$ Both HTS and VE meet these international criteria.
} 
HTS Theological Studies, the reason for not including HTS was based on their "current coverage priorities" and not on the "quality of research included in your journal". It was also stated that "we are familiar with such conditions as imposed by certain governmental bodies around the globe. However, as far as we are concerned, this constitutes a serious misuse of our services and the data we make available". IBSS refused indexing because "religion ... is not considered to be a core discipline. In line with this, we only take journals that cover this from a social science or anthropological perspective, rather than a theological one". Furthermore, "Religious Studies is what IBSS would term a "supportive or complimentary discipline". The discipline of theology seems therefore to be incompatible with the requirements set by these bodies. ${ }^{13}$

Another difference between the Natural Sciences and the Humanities concerns the way in which a journal's impact factor is measured in terms ofthe commercial aspect associated with the impact of a citation. While ISI and IBSS sell articles in journals on account of the scientific impact of their sales, it is not the practice of the Humanities and Theology. In most instances theological articles are not sold to determine their citation impact. Authors in the Humanities (Theology included) are very often cited in order to reject the cited scholar's viewpoint or thesis. Citations in the Humanities are therefore not accurately or empirically measured to determine a positive scholarly impact as is the case with the Natural Sciences. Further attempts will be made by the editors of both HTS and Verbum et Ecclesia to apply for listing on either the ISI or IBSS index.

This state of affairs requires alternative indexing and measurement of the journals' impact factor. With the abovementioned perspectives in mind, it is apparent that because of the difference in character between Natural Sciences and the Humanities, the latter should be viewed in terms of categories/criteria that are more appropriate than those that apply to the Natural Sciences. Moreover, the commercial aspect which plays a role in the ISI and IBSS indexing system, does not do justice to the measurement of the impact factor of disciplines in the Humanities.

We therefore suggest that Verbum et Ecclesia and HTS Theological Studies (and other) South African theological journals, which appear on the accredited list of journals of the DoE, and which are simultaneously indexed on one or more of the following three indexes, be deemed to beof the same

\footnotetext{
${ }^{13}$ Correspondence received from both indexes, however, confirm the scholarly quality and integrity of the HTS Theological Studies as the oldest South African journal. In one of its letters, the ISI also objects in writing to the fact that it is used by the South African

Department of Education as criterion for subsidies. Currently, one South African theological journal are indexed by ISI (Acta Theologica) and none by the IBSS. In Prof Mouton's view it is unlikely to happen in future, the reason being that South African theological journals do not serve the commercial needs of these international indexes.
} 
quality and value as the University of Pretoria's other accredited journals . These indexes are: (1) ATLA Religion Database, (2) IBZ (International Zeitschriftenschau und Grenzgebiete / International Review of Biblical Studies / Revue Internationale des Études Bibliques (3) Elenchus of Biblical Bibliography (of the Editrice Pontficio Instituto Biblico). The indexes have a clear international accepted policy with assessment standards as described at the beginning of the article.

It is important to reiterate that it is the Faculty of Theology's priority to serve the University of Pretoria and the academic community with scientific research of the highest standard. This standard increasingly motivates more international scholars to publish in HTS Theological Studies and Verbum et Ecclesia.

\section{Works consulted}

ASSAf 2006. Report on strategic approach to research publishing in South Africa. Pretoria: Academy of Science of South Africa.

Crewe, R 2006. Verslag dui nié op krisis vir Afrikaans as wetenskapstaal. Rapport, 5 November 2006.

Hendrickx, B (ed) 2007. Ekklesiastikos Pharos 89 (2007) N.S. 18. Johannesburg: The Institute for Afro-Hellenic Studies.

Human, D J \& Groenewald, A (eds) 2007. Verbum et Ecclesia 28(2) (2007). Centurion: Medpharm Publications.

Mouton, J 2007. Theology journals in South Africa. Unpublished presentation by Johann Mouton, director of CREST, Stellenbosch, at the University of Pretoria, 14 March 2007.

Pont, A D 1994. Die Hervormde Teologiese Studies na vyftig jaar. HTS 50(1\&2), 813.

Rademeyer, A 2006. Universiteit-kwaliteit is relatief, sê kenners: Vermeldings "nie die enigste maatstaf vir instellings". Beeld, Donderdag 16 November 2006.

Van Aarde, A G (ed) 2007. HTS Teologiese Studies / Theological Studies 63(4) (2007). Pretoria: B B Print. 


\section{ADDENDUM}

\section{A HTS STATISTICAL INDEX}

\section{4 - 2006:211 published articles}

\begin{tabular}{l|l|}
\hline Foreign authors: & $41=19 \%$ \\
Afrikaans: & $86=41 \%$ \\
English: & $121=57 \%$ \\
Other languages: & $4=2 \%$ \\
"In house": & $82=39 \%$ \\
External non- & \\
$\begin{array}{l}\text { DRC associated } \\
\text { institutions: }\end{array}$ & $129=61 \%$ \\
\hline
\end{tabular}

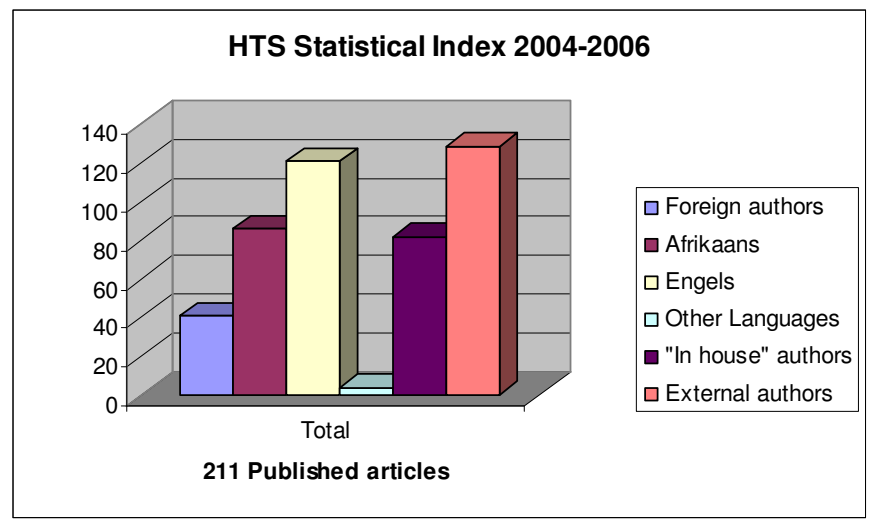

\begin{tabular}{|c|c|c|c|c|c|}
\hline$\frac{2004=76}{\text { articles }}$ & & $\begin{array}{l}2005=70 \\
\text { articles }\end{array}$ & & $\begin{array}{l}2006=65 \\
\text { articles }\end{array}$ & \\
\hline $\begin{array}{l}\text { Foreign authors: } \\
\text { Afrikaans: } \\
\text { English: } \\
\text { Other languages: } \\
\text { "In house": } \\
\text { External non- } \\
\text { NHKA associated } \\
\text { institutions: }\end{array}$ & $\begin{array}{l}5=7 \% \\
40=53 \% \\
34=45 \% \\
2=2 \% \\
31=41 \%\end{array}$ & $\begin{array}{l}\text { Foreign authors: } \\
\text { Afrikaans: } \\
\text { English: } \\
\text { Other languages: } \\
\text { "In house": } \\
\text { External non- } \\
\text { NHKA associated } \\
\text { institutions: }\end{array}$ & $\begin{array}{l}20=29 \% \\
20=29 \% \\
48=69 \% \\
2=2 \% \\
27=39 \%\end{array}$ & $\begin{array}{l}\text { Foreign authors: } \\
\text { Afrikaans: } \\
\text { English: } \\
\text { Other languages: } \\
\text { "In house": } \\
\text { External non- } \\
\text { NHKA associated } \\
\text { institutions: }\end{array}$ & $\begin{array}{l}16=25 \% \\
26=40 \% \\
39=60 \% \\
0 \\
24=37 \%\end{array}$ \\
\hline
\end{tabular}

\begin{tabular}{|c|c|c|c|c|c|}
\hline HTS 60, 2004 & & HTS 61, 2005 & & HTS 62, 2006 & \\
\hline $1^{\text {st }} \& 2^{\text {nd }}$ edition & & $1^{\text {st }} \& 2^{\text {nd }}$ edition & & $1^{\text {st }}$ edition & \\
\hline Foreign authors: & 3 & Foreign authors: & 17 & Foreign authors & 2 \\
\hline Afrikaans: & 16 & Afrikaans: & 7 & Afrikaans: & 5 \\
\hline English: & 18 & English: & 23 & English: & 10 \\
\hline Other languages: & 0 & Other languages: & 1 & Other languages: & 0 \\
\hline "In house": & 14 & "In house": & 10 & "In house": & 4 \\
\hline $\begin{array}{l}\text { External non- } \\
\text { NHKA }\end{array}$ & & $\begin{array}{l}\text { External non- } \\
\text { NHKA }\end{array}$ & & $\begin{array}{l}\text { External non- } \\
\text { NHKA }\end{array}$ & \\
\hline institutions: & 20 & institutions: & 21 & institutions: & 11 \\
\hline $\begin{array}{l}\text { Number of } \\
\text { articles: }\end{array}$ & 34 & $\begin{array}{l}\text { Number of } \\
\text { articles: }\end{array}$ & 31 & $\begin{array}{l}\text { Number of } \\
\text { articles: }\end{array}$ & 15 \\
\hline Edition 3 & & Edition 3 & & Edition 2 & \\
\hline Foreign authors: & 1 & Foreign authors: & 1 & Foreign authors: & 6 \\
\hline Afrikaans: & 18 & Afrikaans: & 0 & Afrikaans: & 6 \\
\hline English: & 10 & English: & 18 & English: & 11 \\
\hline Other languages: & 1 & Other languages: & 0 & Other languages: & 0 \\
\hline "In house": & 14 & "In house": & 11 & "In house": & 8 \\
\hline
\end{tabular}




\begin{tabular}{|c|c|c|c|c|c|}
\hline $\begin{array}{l}\text { External non- } \\
\text { NHKA } \\
\text { institutions: } \\
\text { Number of } \\
\text { articles: } \\
\text { Edition } 4 \\
\text { Foreign authors: } \\
\text { Afrikaans: } \\
\text { English: } \\
\text { Other languages: } \\
\text { "In house": } \\
\text { External non- } \\
\text { NHKA } \\
\text { institutions: } \\
\text { Number of } \\
\text { articles: }\end{array}$ & $\begin{array}{l}1 \\
6 \\
6 \\
1 \\
3\end{array}$ & $\begin{array}{l}\text { External non- } \\
\text { NHKA } \\
\text { institutions: } \\
\text { Number of } \\
\text { articles: } \\
\text { Edition 4 } \\
\text { Foreign authors: } \\
\text { Afrikaans: } \\
\text { English: } \\
\text { Other languages: } \\
\text { "In house": } \\
\text { External non- } \\
\text { NHKA } \\
\text { institutions: } \\
\text { Number of } \\
\text { articles: }\end{array}$ & $\begin{array}{l}2 \\
13 \\
7 \\
1 \\
6 \\
15\end{array}$ & $\begin{array}{l}\text { External non- } \\
\text { NHKA } \\
\text { institutions: } \\
\text { Number of } \\
\text { articles: } \\
\text { Edition } 3 \\
\text { Foreign authors: } \\
\text { Afrikaans: } \\
\text { English: } \\
\text { Other languages: } \\
\text { "In house": } \\
\text { External non- } \\
\text { NHKA } \\
\text { institutions: } \\
\text { Number of } \\
\text { articles: } \\
\text { Edition } 4 \\
\text { Foreign authors: } \\
\text { Afrikaans: } \\
\text { English: } \\
\text { Other languages: } \\
\text { "In house": } \\
\text { External non- } \\
\text { NHKA } \\
\text { institutions: } \\
\text { Number of } \\
\text { articles: }\end{array}$ & $\begin{array}{l}18 \\
4 \\
10 \\
5 \\
0 \\
8 \\
7 \\
\\
15\end{array}$ \\
\hline
\end{tabular}

B Verbum et Ecclesia STATISTICAL INDEX

\begin{tabular}{|c|c|c|c|c|c|c|c|c|c|c|}
\hline & $\begin{array}{l}\text { Vol } \\
24(1) \\
2003 \\
\end{array}$ & $\begin{array}{l}\text { Vol } \\
24(2) \\
2003 \\
\end{array}$ & $\begin{array}{l}\text { Vol } \\
25(1) \\
2004 \\
\end{array}$ & $\begin{array}{l}\text { Vol } \\
25(2) \\
2004 \\
\end{array}$ & $\begin{array}{c}\text { Vol } \\
26(1) \\
2005 \\
\end{array}$ & $\begin{array}{c}\text { Vol } \\
26(2) \\
2005 \\
\end{array}$ & $\begin{array}{l}\text { Vol } \\
26(3) \\
2005 \\
\end{array}$ & $\begin{array}{l}\text { Vol } \\
27(1) \\
2006 \\
\end{array}$ & $\begin{array}{l}\text { Vol } \\
27(2) \\
2006 \\
\end{array}$ & Total \\
\hline $\begin{array}{l}\text { Number of } \\
\text { Articles }\end{array}$ & 18 & 19 & 17 & 23 & 17 & 16 & 13 & 20 & 17 & 160 \\
\hline $\begin{array}{l}\text { Number } \\
\text { Afrikaans }\end{array}$ & 10 & 8 & 11 & 6 & 3 & 6 & 1 & 13 & 2 & 60 \\
\hline $\begin{array}{l}\text { Number } \\
\text { English \& } \\
\text { Other }\end{array}$ & 8 & 11 & 6 & 17 & 14 & 10 & 12 & 7 & 15 & 100 \\
\hline $\begin{array}{l}\text { UP } \\
\text { Contribution }\end{array}$ & 10 & 11 & 9 & 19 & 14 & 2 & 6 & 13 & 4 & 88 \\
\hline $\begin{array}{l}\text { Non-UP - } \\
\text { International }\end{array}$ & 1 & 2 & 2 & 1 & 0 & 4 & 2 & 2 & 8 & 22 \\
\hline $\begin{array}{l}\text { Non-UP - } \\
\text { National }\end{array}$ & 7 & 6 & 6 & 3 & 3 & 10 & 5 & 5 & 5 & 50 \\
\hline
\end{tabular}



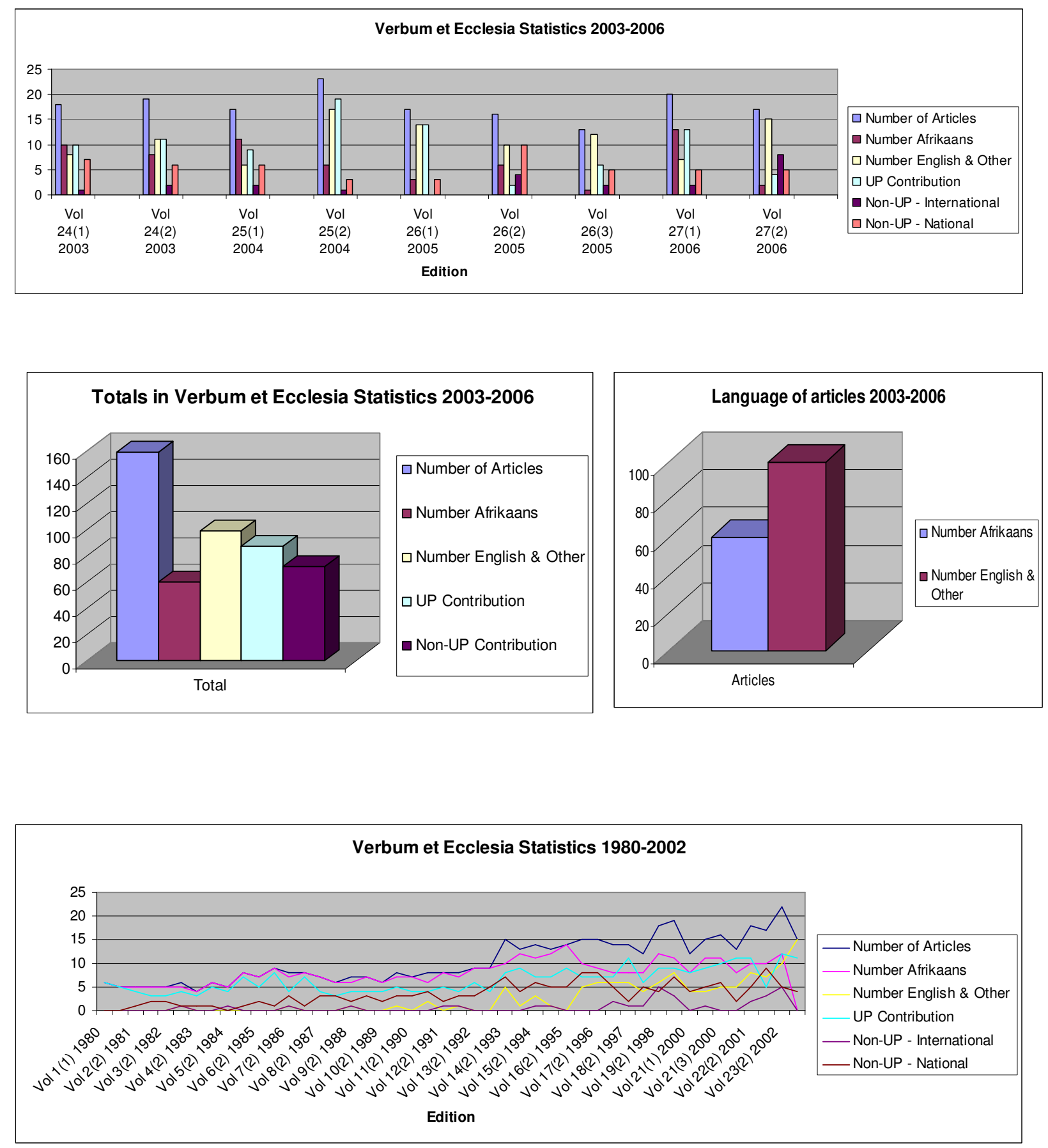

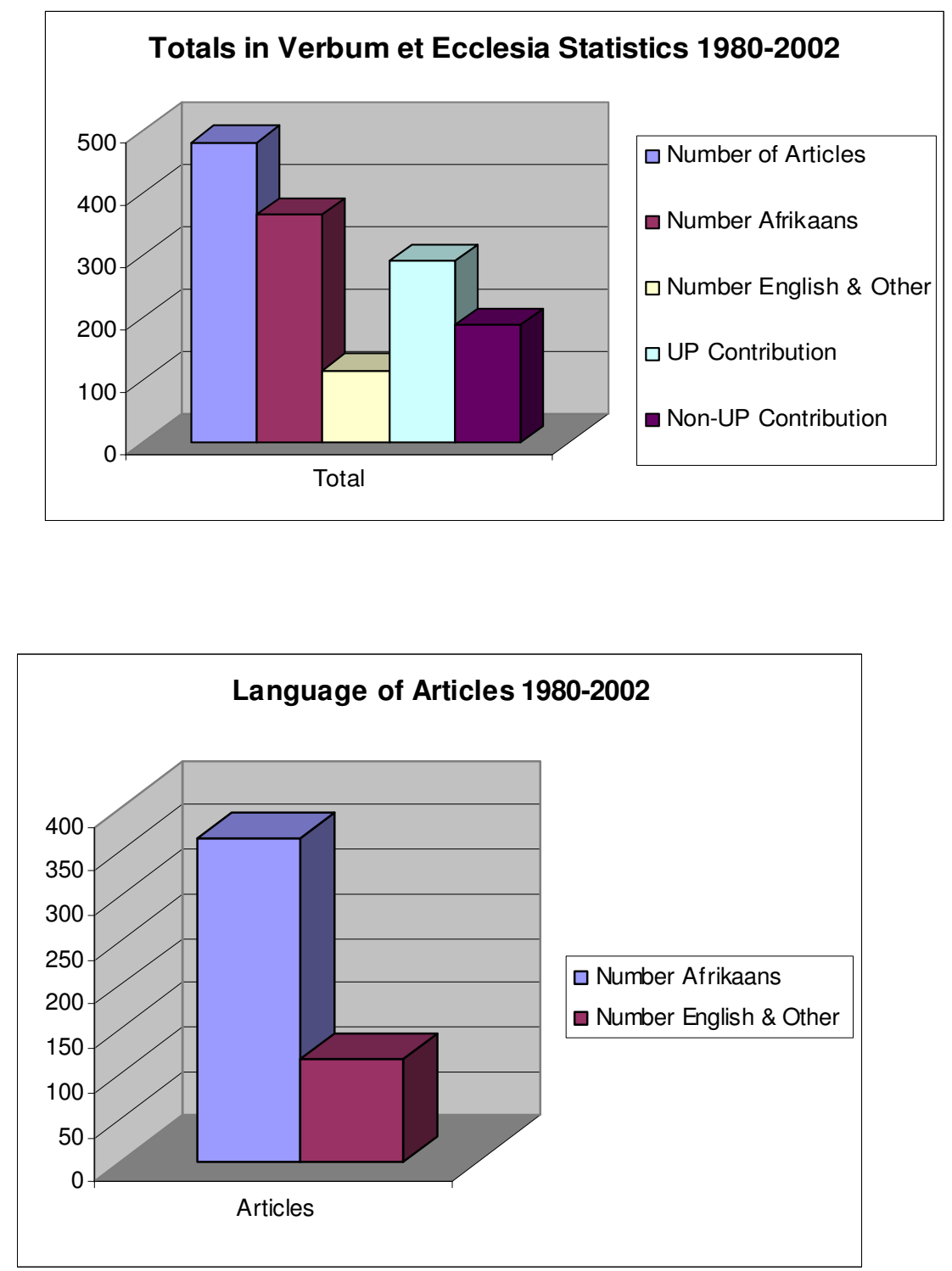